\title{
The Islamic Mystical Spiritual Music Tradition in the Era of New Musical Tendencies
}

\author{
Aida Islam ${ }^{1} \&$ Stefanija Leskova-Zelenkovska ${ }^{2}$ \\ ${ }^{1}$ Faculty of Pedagogy "Ss Kliment Ohridski”, Cs Cyril an Methodius University, Skopje, R. Macedonia \\ ${ }^{2}$ Faculty of Music, University “Goce Delchev” Shtip, Shtip, R. Macedonia \\ Correspondence: Aida Islam, Faculty of Pedagogy "Ss Kliment Ohridski”, Cs Cyril an Methodius University, \\ Bulevar 8-mi Septemvri, 1000 Skopje, R. Macedonia. Tel: 389-71-298-100. E-mail: aidaberkin@yahoo.com
}

Received: December 12, 2011

Accepted: January 26, 2012 Published: May 1, 2012

doi:10.5539/ass.v8n6p170

URL: http://dx.doi.org/10.5539/ass.v8n6p170

\begin{abstract}
Our research on the music tradition perspectives during the periods similar to the current 21 st century conditions in the Republic of Macedonia resulted in findings that reveal significant modifications in the musical expressions. We perceive these changes as an outcome of the individual and collective cultural identities, which are derived from both the ethnicity and domination of the global tendencies. Though these two ongoing and sequential "live" processes are dissimilar in nature, they are also complementary to each other in certain segments to such an extent that the specifics of their music products encompass the most subtle elements of the spiritual tradition. The main objective of this study is to present the cultural identity's impact on the musical segments in the spiritual mystical tradition in the Republic of Macedonia, where there are four dervish orders active at the moment: Rifai, Halveti, Bektashi, and Melami. Due to the complexity of this phenomenon, we have restricted our field of theoretical and research interest to spiritual music in the rites of the Rifai order. Rifai was considered to be the only dervish order in which there have been alterations in the ethnicity of the followers of the tarikat; hence, we believed this to be the most radiant example for our initial thesis. The qualitative research involved analyses of digitalized music contents that were performed on the occasion of the festive dhikirs during the period 2008-2009. Collected data validate the manifestation of certain modifications in the musical expression, developed by the recognition of particular segments from the global music culture and also as a result of the ethnic-cultural identity.
\end{abstract}

Keywords: ethnic-cultural identity, global tendencies, mystical musical tradition, contemporary conditions

\section{Introduction}

The contemporary lifestyle during the transition period from the 20th to the 21 st century is characterized by numerous changes in the global culture, such as the predominance of electronic media, electronic communications, and digitalization. Globalization - a term frequently used in the modern societies - which would not have happened without the digital technology and other technologies, consists of a rapid and abundant exchange of information across the globe (Taylor 2001:119). Due to this technical process, cultural traditions are undergoing modifications in versatile forms of technological novelties.

As a segment of culture, music is more exposed to the newly created circumstances, mainly through the integration of the new technical and technological achievements. We are witnesses to the fact that this process is reflected everywhere where music is present in various forms and to a different extent. Therefore, we wish to stress the absolute predominance of the production and reproduction means through digital sound media, sound processors, etc. This is even more evident through music instruments, which changed and broadened their sound and even the music itself.

These new trends inspired us to concentrate more on the effect they have on the Islamic spiritual tradition. Our main aim was to see whether or how much these novelties are reflected on the sound in the musical segment of the spiritual services. In this study, we analyzed the segment of the spiritual tradition practiced by the dervish orders, since musical instruments are used in some of them. Though the musical characteristics practiced by these mystic orders in the physical and physiological sense do not entirely correspond with the secular viewpoint, in the rites it is still considered the most powerful means for the "education of the individual" (Tezkiye-nefs) and for the "purification of the heart" (Tasviye-i Kulub) (Uludağ 1999: 231). 
Due to the complexity of the phenomenon, we restricted our theoretical and research field of interest to the performance of spiritual music in the dervish rites in the "Vefa Baba" Sadi Tekke in Skopje. Recent research indicates that this tekke has undergone significant changes (Islam 2005; Dzilo 2009). The case study comprises of an analysis of the musical content of the digitalized material used in the segments of the spiritual rites during Eid Al-Fitr, Eid Al-Adha, and Ashura during the years 2008 and 2009.

\section{The Roots of Dervish Orders}

The roots of dervish orders are in sufism, the dervish mysticism, which is a separate methodology of upbringing. The objective of this ideology is to approach, merge, and unite with the Absoluteness, and therefore it is a separate movement and a separate system of thought (Trimingham 1971:1). In fact, it is an aspiration to have mystical relationship with God, i.e., to establish personal contact with Him, for spiritual and life commitment, for transcending the real (limited) world toward intimacy with the Supreme Being (Temkov 2003: 44). The sufis express the subtlety of this thought through poetic expression, music, and movements in the form of dance.

A large number of dervish orders existing in the Islamic civilization today are considered to be the branches of the main 12 dervish orders denoted by the names of their founders: Rifai (Ahmet Rifai-12th century in Iraq), Kadiri (Abdulkadir Geylani-12 ${ }^{\text {th }}$ century in Iraq), Yesevi (Ahmed Yesevi-12 $2^{\text {th }}$ century in Bukhara), Shazeli (Ebul H. Shazeli-12th century in Africa), Mevlevi (Mevlana Dzelaludin Rumi-13 ${ }^{\text {th }}$ century in Anatolia), Bektashi (Bektash Veli-13th century in Iran), Nakshibendi (Mehmet B. Nakshbendi-14th century in Bukhara), Halveti (Omer Halveti-14th century in Iran, Afghanistan), Sadi (Mohammad Sadeddin - 14th century in Sham), Sinani (Ummi Sinan-16th century), Gulshani (Gulshan Ibrahim-16th century in Egypt), and Melami (Omer Sikkini-18th century). Based on the ideological orientation, dervish orders are divided into two branches: Sunnis and Shiites. The difference between these two mystical dervish branches is that the Shiites respect Imam Ali (the son-in-law of Prophet Muhammad (a.s.) to a greater extent, while the Sunnis are the followers of the so-called Ashabi - those who spoke with the Prophet (headed by Abu Bakr) (Elezovic 1925: 10).

Most of the dervish orders are Sunnis. The most important Shiites (Alevis) dervish order is the Bektashi order. Each dervish order is characterized by some specification: dervish orders such as Rifai, Sadi, and Bektashi fostered a military spirit; the Mevlevi-literary, poetic; the Halveti-solitary-silence, meditation, and so on.

The tekkes were institutions, where, in addition to spiritual elevation, certain cultural-educational process was also realized (Oy 1980: 18). Apart from being religious institutions, the tekkes also played a great role in meeting the social needs of the population (Hasluck 1928: 85), which is evident from the fact that a free meal for the population was served there once a day.

Their libraries possessed valuable literary works, mostly poetic creations. There was also significant interest in ornamentation, as well as toward painting, which is obvious from the numerous wall images, on the preparation of wood, plaster or stone mainly with the motifs of the floral world.

\section{The Importance of the Tekkes in the Development of the Spiritual Music}

Within the Islamic conventions, the secular (especially instrumental) music was not favored. The mosques, in contrast to the tekkes, were institutions that played a crucial role in elucidating the doubts within the convention. They have made a valuable contribution to the development of the spiritual, and partly the secular musical life in many ways.

The tekkes (especially of the dervish orders Mevlevi, Kadiri, Bektashi, and Rifai) at the time of the Ottoman State represented the assembling places of esteemed musicians. A number of prominent musicians who were affirmed as the authors of musical theories, the authors of texts or compositions, were in fact members of the dervish orders (Ergun 1942:8). From that aspect, mysticism can be considered as one of the factors that influenced the shaping of forms, poetry, and the melodic structure of the Ottoman music. During that period, spiritual and secular music could not be clearly differentiated. Hence, some of their compositions titled as secular were actually categorized as spiritual (e.g., the composition "Mahur yuruk semai" by Dede Efendi).

\subsection{Musical Forms and Musical Instruments in the Rituals}

Musical tradition at the ritual ceremonies of the dervish orders (especially in the presence of musical instruments) is often associated with the pagan customs of the period before the recognition of Islam: shamanism, animism, and totemism. Thus, for example, the shaman religious persons preached through singing, with the instrument kopuz, a precursor of the saz.

Each of the dervish orders includes a specific ritual ceremony. The ritual in which literature and music are involved usually starts with the so-called "Evrad". It is a literary-musical form composed by the professional musicians, and is performed collectively. Also, in addition to the excerpts from the Quran and the prayers, several musical forms such as the ilahis, qasides, na't, mersije, durak, shugul, nefes, etc. are performed (Özcan 1999: 725/4). 
Unlike the ritual or some of its parts that are performed collectively, the musical forms are usually performed by an individual in-charge called zikir bashi. He chooses the text and the makam of the appropriate music form. As the responsibility is huge, and also because of the requirement of a wide repertoire of spiritual compositions, professional musicians-composers were usually assigned this function.

A close cooperation existed among the various dervish orders, which was also the case in the music field. For example, composers of a certain dervish order often composed for the ritual needs of another dervish order, and so on.

Depending upon the nature of the rituals, various spiritual musical forms such as Ilahi, Qasida, Gazel, Mersije, Nefes, Na't were used.

Ilahi: The ilahis in the mystical music, according to their contents, may be universal, or they may have an affiliation to a certain dervish order. They usually include songs about the topics related to the ideological-philosophical orientation of the order, or about the dignitaries of the dervish order (Öztuna 1969: 297).

Some of the poets whose poems are usually present in these spiritual forms are as follows:

Celaleddin Rumi (1207-1273) - founder of the dervish order Mevlevi;

Yunus Emre (1240-1321) - member of the dervish order Bektashi, who is otherwise one of the most eminent poets in the Turkish literature;

Hacı Bayram Veli (1352-1429)—founder of the dervish order Bayrami;

Eşrefoğlu, Sezai Efendi, Niyazi Misri (1617-1694), and so on (Pennanen 1992: 96).

Typical for poetic creations of these authors is that they mention their names in the last verse of the song, which is called şahbeyit.

In the tekkes are often performed the ilahis with general spiritual content, typical for the mosque music.

Qasida: Together with the ilahis, these represent a spiritual form with religious-philosophical content, and some of these are very lyrical in character.

Gazel: These are songs about mystical love-it is a free secular form in which spiritual texts are adapted. It has improvizing character and performed solo.

Mersije: It is a type of qasida where the pain caused by someone's death is expressed (Akdoğu 2003: 383).

Nefes: This is a music form that is specific to the dervish order Bektashi. The nefes is a form of ilahi composed on the basis of the spiritual poetry of Bektashi poets. The most frequent rhythmic pattern in this form is Devr-i revani (13-beats) or Raksani (15-beats) (Talu, 2000: 16).

The most characteristic musical forms of the ritual ceremonies of Mevlevi are Ayin and Na't:

Ayin: The longest and most complex musical form, which contains four parts called Selam.

$N a$ 't: The form A + B, which usually contains the rhythmic patterns Durak Evferi (21-beats) or Turki Zarb (18-beats).

The texts of the above-mentioned musical forms are mostly in Arabic or Turkish, and rarely in the Persian language. In most of these dervish orders, vocal performance is accompanied by music instruments. Depending on the tradition of the dervish orders, the instruments used are: bendir (or def = daire without bells), kudum, cymbals, ney, kemenje, rebab, etc. The first three instruments are used in almost all the dervish orders, while the others are characteristic of Mevlevi. The ney is particularly associated with the court Ottoman music through the ceremonies of Mevlevi called sema (sema = the dervishes that are spinning around), which were supported by most of the Ottoman rulers.

In most of the dervish orders, the musical instrumentalists were appreciated by the other devotees of the order. In addition, most of the tekkes (especially the Mevlevi) comprised a special part of the room for divine service to accommodate the spiritual musicians during their performance (Elezovic 1925: 16). Each of the dervish orders is characterized by individual traditions, in terms of the choice of texts, the musical forms, or the instruments. Folk tradition dominated the tekkes located in the smaller settlements, whereas classical court tradition had a major influence on the tekkes in the cities (Yahya 2001: 63).

\section{The Dervish Orders in R. Macedonia}

During the Ottoman period from the 15th to the 20th century in Macedonia were built 77 tekkes, where all the dervish orders were represented (Çelebi 1979). During the last century, their number has drastically reduced. One of the main reasons is due to the mass migration of the Turkish population to the Republic of Turkey, especially during the $50 \mathrm{~s}$. 
Four dervish orders are active at the moment, Rifai with the branch Sadi, Halveti, Bektashi, and Melami.

The greatest modifications in relation to the musical characteristics are evident among Sadi, who practiced identical rituals with Rifai. During the last six decades, significant changes occurred gradually in their musical characteristics, which had completely separated them from the Rifai order. Changes are related to the following segments of the musical tradition: (1) the use of musical instruments-the expansion of the rhythmic percussion forms with melodic; (2) the emergence of new musical forms; (3) the change in language; (4) the openness and broad access to the rituals.

\subsection{The Sadi Dervish Order, Today}

The Sadi dervish order has been active since the late 19th century (Ulema meclis K.: 85) solely at the "Vefa Baba" Tekke in Skopje. The founder of the tekke was Sheikh Vefa Baba from Turkey who was succeeded by Sheikh Mehmet Ali. With his migration to Turkey in 1950, the succession of the tekke "by merit" (erbabiye) was transferred to Sheikh Shaban. Since then, this dervish order has been run by members of the Roma community: Sheikh Rufat, Sheikh Rushdi, and, at present, Sheikh Ali Riza Ajdin. Besides being a place for the tarikat rituals and rites, the "Vefa Baba" Tekke also serves as a mosque (Dzilo 2000). Sheikh Vefa Baba, as well as Sheikh Mehmet Ali and Sheikh Rifat were all buried in the turbe next to the house of prayer.

\subsection{The Music Tradition in the Spiritual Rite}

As an integral part of the rites (dhikir), the music in the Sadi Tekke "Vefa Baba" is a rather important segment, especially since it is a part of the loud tarikat (Cehr-i tarikat).

Generally, the spiritual rite of this dervish order begins with an interpretation of sura from the Quran, followed by a repetition of the Kelime - i tevhid "La ilaha illallah" as well as some of God's names: Hu, Hayy, Allah, Daim, or Kuyyum. Depending upon the situation, the dhikir could be held standing up (Zikr-i kiyam) or sitting down (Kaiden zikir), often with a spontaneous, rhythmic, circular body movement (Halka zikir).

The scope and the structure of the musical content are different for the everyday and the festive rites. The everyday rites are held on Fridays at noon and on Sundays' evening, and are led by the Sheikh himself. Here, ilahis and gazels a cappella or accompanied by a rhythmical instrument such as def, kudum, or drums are performed. Dhikirs are held on important Islamic holidays such as Eid Al-Fitr, Eid Al-Adha, and Ashura, and have a ceremonial and formal character reflected in the richness of the music content, which is always accompanied by versatile instruments.

\section{Research Results}

The solemnity in the holiday rites is reflected in the usage of specific attire, depending on the hierarchical position. The dervishes from the highest rank wear ceremonial garments (haydariye).

The music repertoire during the ceremony is widened and is grouped into several ritual cycles. Each part comprises of roughly 10 ilahis and gazels, which, to be synchronized and performed successfully, need to be well prepared and rehearsed. The music performance led by the master of the ceremonies (Zikirbaş1) has a predetermined program and consists of responsorial and a collective performance, depending on the musical form. The group performance is present in ilahis. In the gazels, the interpretation is two-voice and is achieved by bordun of a group of young members who call out one of the names of the Almighty or Kelime-i tevhid "La ilaha illallah". The Zikirbaşı performs the gazel to improvize the melodic line, which further enhances the transcendental state, all in order to achieve the divine love of God (aşk).

The scope of the musical repertoire has been reduced from around 200 forms in the past to around 10 ilahis and gazels in the last decades. This is due to the fact that it is rather specific to convey music forms verbally and also that the young generation has insufficient knowledge of the Turkish language.

The prevailing ilahis today are "Vasil olmaz kişi," "Sordum sarı çiçeğe," "Muhammed'e doyamadım," "Sevdim seni Mabuduma," "Ötme bülbül". Poets whose poems are most frequently performed in these spiritual forms are: Celaleddin Rumi, Yunus Emre, Beytullah, Hacı Bayram Veli, Ali Ulvi Kurucu, Eşrefoğlu, Sezai Efendi, and so on (Pennanen 1992: 96).

According to the musical form, examples of two-part and three-part songs can be found: $\mathrm{a} b$ or $\mathrm{a} \mathrm{b} \mathrm{c} \mathrm{b}$. The small rhythmic patterns (usuls) are characteristic for ilahis, as in Sofyan (4/4, 4/8), Düyek and Müsemmen (8/4, 8/8), Evfer $(9 / 4,9 / 8)$, and others. Sometimes, larger usuls are written, such as Devr-i kebir (28/4), Evsat (26/4), Çember (24/4), etc. The music samples that were the subjects of our analysis mainly contain Sofyan (4/4).

A rather significant characteristic of the dhikir is the integration of melodies of the secular music. These melodic acquisitions are part of a wider genre segmentation, typical of the contemporary music culture. The new genre 
helps in attracting the more versatile age structure of visitors. Such was the case with the "Üsküdara gider iken" song.

Beside the Arabic and Turkish languages, some musical forms are performed in the Roman language as well. This is done to overcome the language barrier, as well as to help familiarize the wider population with the spiritual texts.

In holiday dhikir, versatile musical instruments such as synthesizers, clarinet, saz, and daf are used. The extent to which each of the instruments is used depends mainly on the current music potential of the participants in the celebration, since people outside of the community are often included. The presence of the synthesizer results in the modification of both the sound color and the structure of the melody of the modes called makams, which are typical of the Turkish music. This is due to the fact that it is generally impossible to perform the micro-intervals in this mode on a tempered instrument.

The Sadi dervish order instigate the transcendent state through poetic expression and constant change of rhythmic structure, followed by a change in tempo, dynamics, usage of accelerando, and chromatic modulations.

\section{Conclusion}

The research results confirm that there are apparent changes in the sound in the musical segment of the Sadi spiritual rites in Skopje. They are the result of global technical and technological novelties and they imply the integration of various instruments and electronic aids as an inevitable process in the contemporary music environment. Here are also the video recordings of segments of the spiritual rites, which make their contents, mainly mystical (tasavvuf), more accessible to a wider population. The modifications of the musical expression in the Sadi rites in the "Vefa Baba" Tekke in Skopje are meant to further strengthen the tekke's position in the community, to open its doors, and to maintain the community's interest in this institution - all part of the ideology which, besides the spiritual dimension, always maintains the cultural and educational one as well.

\section{References}

Akdoğu, Onur, (2003). Türler ve Biçimler. İzmir: Meta Basım.

Čehajić, Dzemal. (1986). Derviski redovi u Jugoslovenskim Zemljama. Sarajevo

Čehajić, Dzemal. (1985). Drustveno-politicki, Religiozni, Knjizevni i drugi aspekti derviskih redova u Jugoslovenskim zemljama. Prilozi za Orijentalnu Filologiju, XXXIV, Sarajevo.

Čelebi, Evlija. (1979). Putopis. Odlomci o jugosovenskim zemljama. Sarajevo.

Dzilo, Hasan. (2000). The Dervish Order Rifai in Macedonia (manuscript).

Elezovich, Glisha. (1925). Turski spomenici u Skopqu. Skopqe: GSND.

Elezovich, Glisha. (1925). Dervishki redovi muslimanski-Tekije u Skoplju. Skopje: Stara Srbija.

Ergun, Nüzhet Sadeddin. (1942). Türk Müsikisi Antolojisi, cilt 1. Istanbul.

Hasluck, F.W. (1973). Christianity And Islam Under The Sultans. New York.

Hasluck, F.W. (1928). Trans. Ragip Hulusi. Bektasi Tekkeleri. Istanbul.

Islam, Aida. (2005). The Reflections of the Ottoman Music Culture on the Contemporary Music Culture of the Turkish Community in Republic of Macedonia(doctoral thesis).

Markoff, Irene. (1995, Dec.). Introduction to Sufi Music and Ritual in Turkey. MESA Bulletin.

Oy, Aydin. (1980). Kalkandelende Harabati Baba Tekkesi. "Cevren". Pristina.

Özcan, Nuri, (1999). 17. ve 18. Yüzyıllarda Osmanlılarda dini musikisi. Osmanlı Kultür ve Sanat, cilt 10. Ankara.

Öztuna, Yılmaz. (1976). Türk Musikisi Ansiklopedisi. Istanbul: Milli Eğitim Basımevi, 250.

Pennanen, R. Pekka. (1992). The Mith of Sufi Music. Istanbul - Paris: Editions Isis.

Talu, R. Hakan. (2002). Aşk ile... Istanbul: Pan Yayınc1lık.

Taylor, D. Timothy. (2001). Strange sounds-music ,technology \& culture. London: Routledge.

Trimingham, J. Spencer. (1971). The Sufi Orders In Islam. Oxford University Press.

Ulema meclis, K.: 85, fond. Arhiv na R. Makedonija. Skopje.

Uludağ, Süleyman. (1999). Musiki ve Semâ. Istanbul: Marifet Yayinlari.

Yahya, Abaz. (2001). Makedonya' da Tekkeler ve Tekke Musikisi (master’s thesis).

Yılmaz, Zeki. (2001). Türk Musikisi Dersleri. İstanbul: Çağlar yayınlar. 